\title{
GC-MS ANALYSIS AND BIOACTIVE COMPONENTS OF FLOWERS OF Bergenia ciliata, A WEED OF ROCK CREVICES IN PAKISTAN
}

Malik F. H. Ferdosi ${ }^{1}$, Iqra Haider Khan ${ }^{2}$, Arshad Javaid ${ }^{2 *}$, Hafiz Muhammad Saeed ${ }^{1}$, Ifrayeem Butt ${ }^{2}$ and Ayesha Munir ${ }^{3}$

DOI: https://doi.org/10.28941/pjwsr.v27i4.1012

\begin{abstract}
Bergenia ciliata is a weed of hilly areas of Pakistan that generally grows in rock crevices. In the present study, flowers of this weed were collected from Murree, Pakistan. The dried flowers were extracted in methanol and subjected to GC-MS analysis that showed 7 compounds in it. The predominant compound was hexanedioic acid, bis(2ethylhexyl) ester (48.88\%) followed by $Y$-sitosterol $(22.56 \%)$. Moderately occurring compound was cyclohexane, 1,3,5-triphenyl- (12.87\%). The remaining compounds namely $n$-hexadecanoic acid (4.97\%), pentadecanoic acid, 14-methyl-, methyl ester $(3.77 \%), 9,12$-octadecadienoic acid, methyl ester, $(Z, Z)-(2.94 \%)$ and $9,12,15-$ octadecatrienoic acid, methyl ester, $(Z, Z, Z)-(2.92 \%)$ were categorized as less abundant compounds. Literature survey indicated that these compounds possess antimicrobial, larvicidal, anti-inflammatory, anticancer and/or antidiabetic properties.
\end{abstract}

Keywords: Bergenia ciliata, Bioactive compounds, Flower extract, Murree, Pakistan.

Citation: Ferdosi, M.F.H.; I.H. Khan; A. Javaid; H.M. Saeed; I. Butt and A. Munir. 2021. GC-MS Analysis and Bioactive Components of Flowers of Bergenia ciliata, A Weed of Rock Crevices in Pakistan. Pak. J. Weed Sci. Res., 27(4): 527-535.

\footnotetext{
${ }^{1}$ Department of Horticulture, Faculty of Agricultural Sciences, University of the Punjab, Quaid-i-Azam Campus, Lahore 54590, Pakistan

2Department of Plant Pathology, Faculty of Agricultural Sciences, University of the Punjab, Quaid-i-Azam Campus, Lahore 54590, Pakistan

*Corresponding author's email: arshad.iags@pu.edu.pk, arshadjpk@yahoo.com
} 


\section{INTRODUCTION}

Plants have been utilized for various purposes since early human civilization. Naturally originated plantbased products play an important role in the discovery process of drug (Ugboko et al., 2020). These provide unlimited opportunities because of their unmatched chemical diversity with potential to develop innovative drugs (Anand et al., 2019; Salmerón-Manzano et al., 2020). Plants have a wide range of compounds that can be used for treatment of infectious as well as chronic diseases in traditional medicine system (Boy et al., 2018; Khan and Javaid, 2020a; Javaid et al., 2021). Chemically synthesized drugs have adverse effects therefore, these turned scientists' attention towards the ethnopharmacognosy (Zeidali et al., 2021). Plant derived phytochemicals are broadly effective with much safer and less adverse effects. Many biological activities such as antimicrobial, anticancer, wound healing, antidiarrheal, analgesic, antioxidant have been found associated with the use of plants (Riaz et al., 2008; Oladeji et al., 2019; Javed et al., 2021).

Bergenia ciliata belongs to family Saxifragaceae, is an evergreen small perennial weed plant that is commonly known as winter bergonia (Kumar et al., 2020). It is mostly distributed in the cold and temperate regions of Pakistan, Nepal, Bhutan, India and some other countries (Ali et al., 2020). It has been used in traditional ayurvedic medicine to treat several diseases including fever, diarrhea, pulmonary affections, cough, vomiting and menorrhagia (Ahmad et al., 2018; Zafar et al., 2019). B. ciliata contains a variety of substances belonging to terpenoids, flavonoids, sterols, glycosides and saponins (Hussain et al., 2019). The major steps to use compounds of biologically importance from plant resources include extraction, pharmacological screening, isolation and identification (Oreopoulou et al., 2019). The literature search on $B$. ciliata showed that very little work has been done on phytochemical analysis of flowers of this plant especially in Pakistan. Therefore, in the present study, B. ciliata flowers were extracted in methanol and its GC-MS analysis was done to explore its phytochemical profile.

\section{MATERIALS AND METHODS Collection of flowers}

Flowers from healthy $B$. ciliata plants growing in a rock crevice at Hill Fruit Research Station, Sunny Bank, Murree, Pakistan were collected during March 2021 and packed in paper bags to avoid moisture and contaminants. These samples were shifted to the laboratory in Punjab University Lahore for further experimentation and analysis. Identification of the specimen was done by Dr. Faheem Arshad, Chairperson Department of Botany, University of Okara, Pakistan.

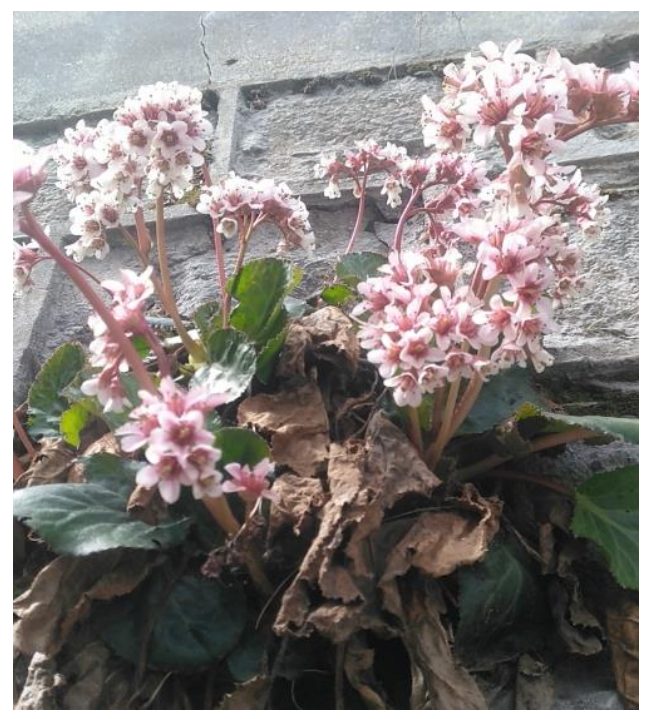

Fig. 1: Bergenia ciliata growing in crevices at Sunny Bank, Murree. 


\section{Preparation of Methanolic extracts}

The flowers were kept in steel strays and dried thoroughly for 5 days at room temperature. To ensure complete moisture evaporation, the trays were placed at $35^{\circ} \mathrm{C}$ in hot air oven for $24 \mathrm{~h}$. Subsequently, the flowers were ground into fine powder with the help of a mortar and pestle. Thereafter, $10 \mathrm{~g}$ of fine powdered of $B$. ciliata flowers were soaked in $50 \mathrm{~mL}$ of methanol in a 250$\mathrm{mL}$ conical flask and left for two weeks. The methanolic extract was separated from the dipped material by using muslin cloth and then filtered through double layered filter paper into a sterilized flask. Finally, $2 \mathrm{~mm}$ of extracted material was collected in a vial and subjected to GC-MS analysis for biochemical profiling of $B$. ciliata.

\section{GC-MS analysis}

Gas chromatography (model 7890B), Agilent Technologies, USA was used with the scan range of 50-500 $\mathrm{m} / \mathrm{z}$. The injection volume was $1 \mu \mathrm{L}$; model of the column used was DB 5MS along with the dimensions $30 \mathrm{~m} \times 0.25$ $\mu \mathrm{m} \times 0.25 \mu \mathrm{m}$; the inlet temperature was $280^{\circ} \mathrm{C}$; solvent delay time was 5 min and helium was used as a carrier gas with split less mode. The initial temperature of oven ramping was $80^{\circ} \mathrm{C}$ which was raised to $10^{\circ} \mathrm{C}$ more.

For mass spectroscopy, machine of model 5977A with MS search library having mass hunter/NIST 2017 version was used. The source and the quadrupole temperatures were 230 ${ }^{\circ} \mathrm{C}$ and $150{ }^{\circ} \mathrm{C}$, respectively, with $50 \mathrm{~min}$ run time. Chemical compounds were identified by comparing their spectra with library NIST 2017. The compounds were arranged in an ascending order of their retention time. Further, the relative abundance was reported from respective peak areas. Structures of the identified compound were drawn by using ChemDraw Pro 8.0 software.

\section{Literature survey}

To figure out any previous reports on the bioactivity of compounds that were identified in the flower extract of $B$. ciliata, a comprehensive literature survey was done.

\section{RESULTS AND DISCUSSION}

GC-MS analysis indicated the presence of seven compounds in the methanolic flower extract of $B$. ciliata (Fig. 2). The predominant compound with $46.56 \%$ peak area was hexanedioic acid, bis(2-ethylhexyl) ester. $\mathrm{Y}$-Sitosterol was the second most abundant compound with peak area of $21.06 \%$ followed by cyclohexane, 1,3,5triphenyl- (12.07\%). Other compounds included $n$-hexadecanoic acid (4.64\%), pentadecanoic acid, 14-methyl-, methyl ester $(3.52 \%)$, 9,12-octadecadienoic acid, methyl ester, $(Z, Z)-(2.75 \%)$ and $9,12,15$-octadecatrienoic acid, methyl ester, $(Z, Z, Z)-(2.73 \%)$ (Table 1$)$. Their structures are shown in Fig. 3.

The predominant compound hexanedioic acid, bis(2-ethylhexyl) ester is a plasticizer derivative (Ghisari and Bonefeld-Jorgensen, 2009). However, it has been reported earlier from various living sources namely Streptomyces isolate TN262 (Elleuch et al., 2010), stem of Hugonia mystax (Vimalavady and Kadavul, 2013), roots of Stellera chamaejasme (Xue-Na et al., 2012), wood of Populus tomentosa and $P$. lasiocarpa (Peng et al., 2017), and leaves of Adenophyllum porophyllum (HernándezCeja et al., 2021). Its antifungal activity has been reported against Fusarium sp. (Elleuch et al., 2010), Monilinia fructicola (Xue-Na et al., 2012), Lasiodiplodia pseudotheobromae and Colletotrichum gloeosporioides (Hernández-Ceja et al., 2021). 
530 Malik F. H. Ferdosi, Iqra Haider Khan et al. GC-MS Analysis and Bioactive ....

Table 1: Compounds identified in methanolic flower extract of Bergenia ciliata through GC-MS analysis.

\begin{tabular}{|c|c|c|c|c|c|}
\hline $\begin{array}{l}\text { Sr. } \\
\text { No. }\end{array}$ & Names of compounds & $\begin{array}{l}\text { Molecular } \\
\text { formula }\end{array}$ & $\begin{array}{l}\text { Molecular } \\
\text { weight }\end{array}$ & $\begin{array}{l}\text { Retention } \\
\text { time (min) }\end{array}$ & $\begin{array}{c}\text { Peak } \\
\text { area } \\
(\%)\end{array}$ \\
\hline 1 & $\begin{array}{l}\text { Pentadecanoic acid, 14- } \\
\text { methyl-, methyl ester }\end{array}$ & $\mathrm{C}_{17} \mathrm{H}_{34} \mathrm{O}_{2}$ & 270.45 & 14.367 & 3.77 \\
\hline 2 & $n$-Hexadecanoic acid & $\mathrm{C}_{16} \mathrm{H}_{32} \mathrm{O}_{2}$ & 256.42 & 14.785 & 4.97 \\
\hline 3 & $\begin{array}{l}\text { 9,12-Octadecadienoic acid, } \\
\text { methyl ester, }(Z, Z) \text { - }\end{array}$ & $\mathrm{C}_{19} \mathrm{H}_{34} \mathrm{O}_{2}$ & 294.47 & 16.009 & 2.94 \\
\hline 4 & $\begin{array}{l}9,12,15 \text {-Octadecatrienoic } \\
\text { acid, methyl ester, }(Z, Z, Z) \text { - }\end{array}$ & $\mathrm{C}_{19} \mathrm{H}_{32} \mathrm{O}_{2}$ & 292.45 & 16.067 & 2.92 \\
\hline 5 & $\begin{array}{l}\text { Hexanedioic acid, bis( } 2- \\
\text { ethylhexyl) ester }\end{array}$ & $\mathrm{C}_{22} \mathrm{H}_{42} \mathrm{O}_{4}$ & 370.56 & 18.590 & 48.88 \\
\hline 6 & $\begin{array}{l}\text { Cyclohexane, 1,3,5- } \\
\text { triphenyl- }\end{array}$ & $\mathrm{C}_{24} \mathrm{H}_{24}$ & 312.4 & 19.156 & 12.87 \\
\hline 7 & Y-Sitosterol & $\mathrm{C}_{29} \mathrm{H}_{50} \mathrm{O}$ & 414.70 & 25.434 & 22.56 \\
\hline
\end{tabular}

Table 2: Bioactivity of components of methanolic leaf extract of quinoa.

\begin{tabular}{|c|c|c|c|}
\hline Sr. No. & Names of compounds & Bioactivity & Reference \\
\hline 1 & $\begin{array}{l}\text { Pentadecanoic acid, 14- } \\
\text { methyl-, methyl ester }\end{array}$ & $\begin{array}{l}\text { Antifungal, } \\
\text { antibacterial }\end{array}$ & Bashir et al. (2012) \\
\hline 2 & $n$-Hexadecanoic acid & $\begin{array}{l}\text { Anti-inflammatory, } \\
\text { antioxidant, } \\
\text { nematicidal, pesticidal, } \\
\text { anti-androgenic flavor, } \\
\text { mosquito larvicide, } \\
\text { hemolytic }\end{array}$ & $\begin{array}{l}\text { Kumar et al. } \\
\text { (2010); Aparna et } \\
\text { al. (2012) }\end{array}$ \\
\hline 3 & $\begin{array}{l}\text { 9,12-Octadecadienoic acid, } \\
\text { methyl ester, }(Z, Z) \text { - }\end{array}$ & $\begin{array}{c}\text { Urine acidifier, } \\
\text { anticancer, } \\
\text { hypocholesterolemic, } \\
\text { hepatoprotective }\end{array}$ & $\begin{array}{l}\text { Duke (1992); Yu et } \\
\text { al. (2005); } \\
\text { Sermakkani and } \\
\text { Thangapandian } \\
\text { (2012) }\end{array}$ \\
\hline 4 & $\begin{array}{l}9,12,15 \text {-Octadecatrienoic } \\
\text { acid, methyl ester, }(Z, Z, Z) \text { - }\end{array}$ & $\begin{array}{c}\text { Anti-inflammatory, } \\
\text { anticancer, } \\
\text { nematicidal, } \\
\text { antihistaminic, } \\
\text { anticoronary, } \\
\text { insectifuge, } \\
\text { Cardioprotective }\end{array}$ & $\begin{array}{l}\text { Sermakkani and } \\
\text { Thangapandian } \\
\text { (2012); Godwin et } \\
\text { al. (2015) }\end{array}$ \\
\hline 5 & $\begin{array}{l}\text { Hexanedioic acid, bis(2- } \\
\text { ethylhexyl) ester }\end{array}$ & Antifungal & $\begin{array}{l}\text { Elleuch et al. } \\
\text { (2010); Xue-Na et } \\
\text { al. (2012) }\end{array}$ \\
\hline 6 & $\begin{array}{l}\text { Cyclohexane, } 1,3,5- \\
\text { triphenyl- }\end{array}$ & - & - \\
\hline 7 & Y-Sitosterol & $\begin{array}{l}\text { Anticancer, } \\
\text { Antidiabetic }\end{array}$ & $\begin{array}{l}\text { Balamurugan et al. } \\
\text { (2011); Sundarraj } \\
\text { et al. (2012) }\end{array}$ \\
\hline
\end{tabular}




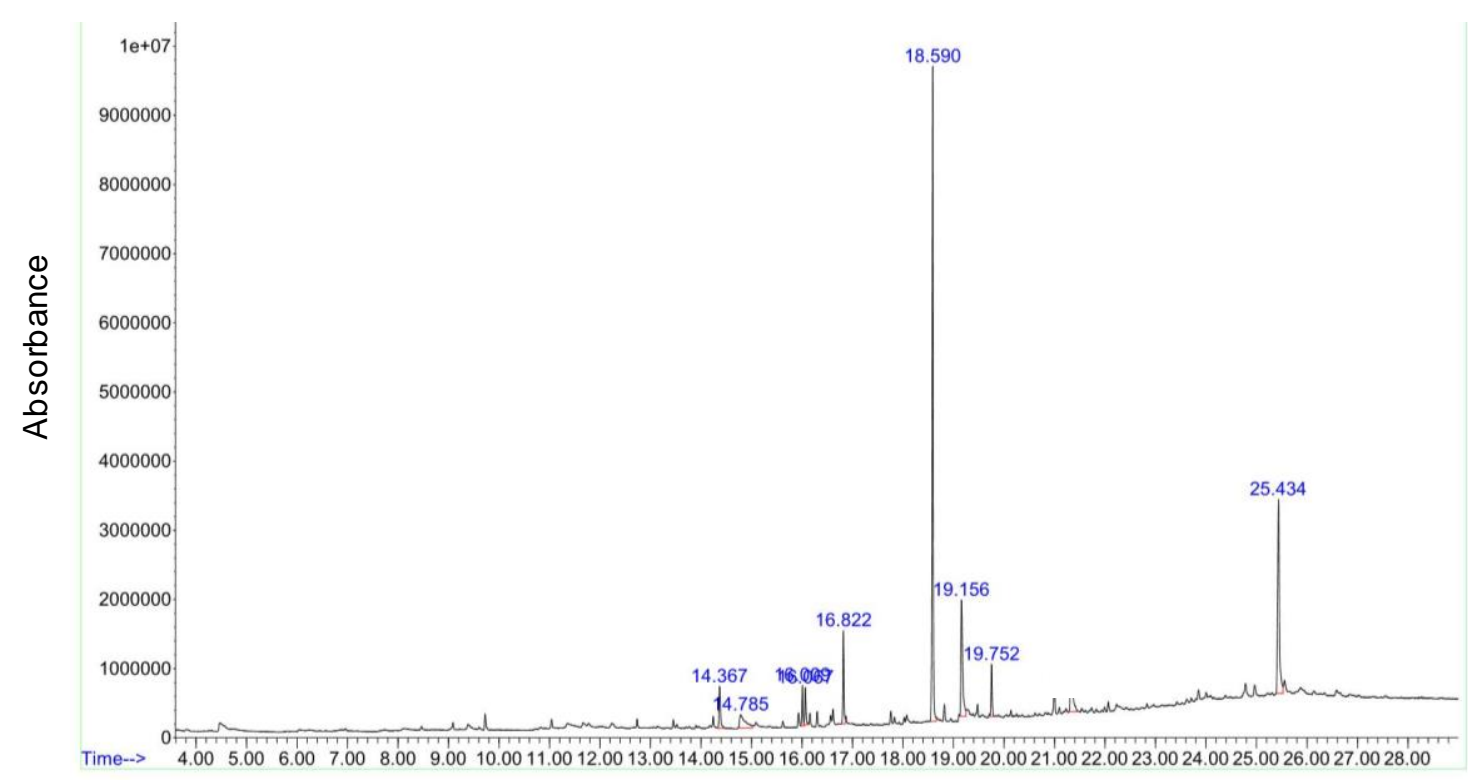

Fig. 2: GC-MS chromatogram of methanolic flower extract of Bergenia ciliata.

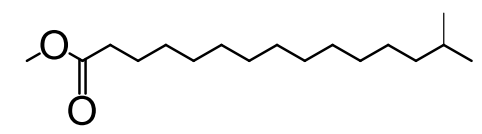

Pentadecanoic acid, 14methyl-, methyl ester

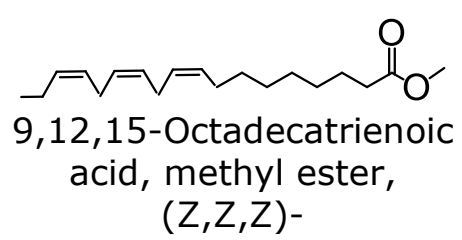

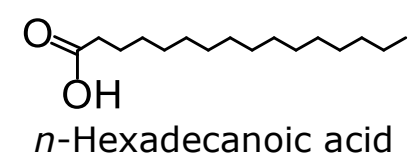

$n$-Hexadecanoic acid

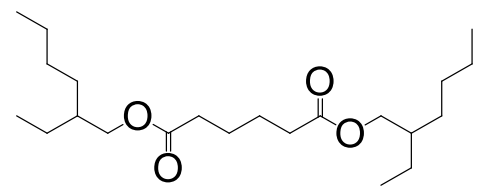

Hexanedioic acid, bis(2-ethylhexyl) ester

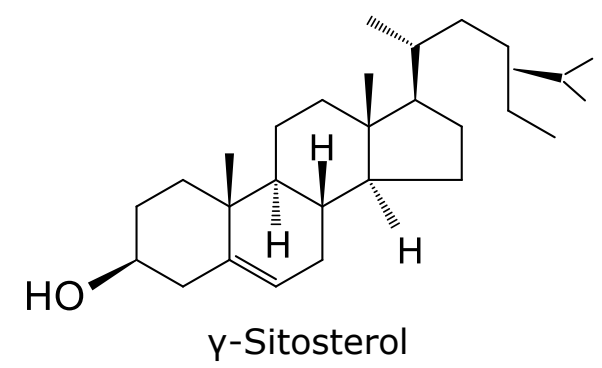<smiles>CCCCC/C=C\C=C/CCCCCC(=O)OC</smiles>
acid, methyl ester, $(Z, Z)-$<smiles>c1ccc(C2CC(c3ccccc3)CC(c3ccccc3)C2)cc1</smiles>

Cyclohexane, 1,3,5triphenyl-

Fig. 3: Structures of compounds present in flower extract of Bergenia ciliata. 
532 Malik F. H. Ferdosi, Iqra Haider Khan et al. GC-MS Analysis and Bioactive ....

The second most abundant compound was $\mathrm{y}$-sitosterol. This naturally occurring steroid has been reported in many plant species including Chenopodium quinoa (Khan and Javaid, 2020b), Calotropis procera (Ferdosi et al., 2021) and Carthamus oxycantha (Rafiq et al., 2021). It has also been reported in metabolites of fungal species such as Trichoderma pseudokoningii (Khan ad Javaid, 2020c). Antidiabetic property of Lippia nodiflora is due to presence of $\mathrm{Y}^{-}$ sitosterol. In addition, this compound also showed antihyperlipidemic activity by decreasing serum total cholesterol, triglycerides in treated rats (Balamurugan et al., 2011). Y-Sitosterol isolated from Acacia nilotica showed marked anticancer activity by arresting cell cycle and the apoptosis on cancer cells (Sundarraj et al., 2012). Extracts of four species of genus Lagerstroemia, with $Y$-sitosterol as the major component (14.70-34.44\%), induced pronounced DNA damage in human peripheral blood mononuclear cells (Sirikhansaeng et al., 2017).

$n$-Hexadecanoic acid or palmitic acid has many biological activities. Its occurrence has been reported in various plant species namely Chenopodium mural, Coronopus didymus and Chenopodium quinoa (Javaid et al., 2018; Khan and Javaid, 2020b; Naqvi et al., 2020), and fungal species such as Trichoderma viride (Khan et al., 2021). It acts as an anti-inflammatory agent by designing of phospholipase $A(2)$ inhibitors (Aparna et al., 2012). It is also reported to have antimicrobial (Abubakar and Majinda, 2016), mosquito larvicidal (Rahuman et al., 2000), hypocholesterolemic, antioxidant, 5-Alpha reductase inhibitor, nematicidal, pesticidal properties (Kumar et al., 2010).

Pentadecanoic acid, 14-methyl-, methyl ester; 9,12-octadecadienoic acid, methyl ester, $(Z, Z)$ - and 9,12,15octadecatrienoic acid, methyl ester, $(Z, Z, Z)$ - are fatty acid methyl esters. These have been found in many plant species including Ageratum conyzoides, Cannabis sativa and Coronopus didymus (Banaras et al., 2021; Javaid et al., 2018, 2021). Methyl esters isolated from Euphorbia kansui showed anticancer activity by initiating growth inhibition and inducing apoptosis in tumor cells (Yu et al., 2005). In additions, previous studies have also shown that fatty acid methyl ester extracts of Arthrocnemum indicum, Suaeda monoica, Sesuvium portulacastrum, Salicornia brachiata, Excoecaria agallocha and Suaeda maritima possess antifungal and antibacterial activities (Agoramoorthy et al., 2007; Chandrasekaran et al., 2008, 2011).

\section{Conclusion}

This study concludes that flowers of $B$. ciliata contain many biologically important compounds especially $n$ hexadecanoic acid, $\mathrm{y}$-sitosterol and fatty acid methyl esters. 


\section{REFERENCES CITED}

Abubakar, M.N. and R.R.T. Majinda. 2016. GC-MS Analysis and preliminary antimicrobial activity of Albizia adianthifolia (Schumach) and Pterocarpus angolensis. Medicines, 3: Article 3.

Agoramoorthy, G., M. Chandrasekaran, V. Venkatesalu and M.J. Hsu. 2007. Antibacterial and antifungal activities of fatty acid methyl esters of the blind-your-eye mangrove from India. Braz. J. Microbiol., 38: 739-742.

Ahmad, M., M.A. Butt, G. Zhang, S. Sultana, A. Tariq and M. Zafar. 2018. Bergenia ciliata: a comprehensive review of its traditional uses, phytochemistry, pharmacology and safety. Biomed. Pharmacother., 97: 708-721.

Ali, E., N. Arshad, N.I. Bukhari, T.M. Nawaz, S. Zafar, A. Hussain and K. Hussain. 2020. Linking traditional anti-ulcer use of rhizomes of Bergenia ciliata (Haw.) to its antihelicobacter pylori constituents. Nat. Prod. Res., 34: 541544.

Anand, U., N. Jacobo-Herrera, A. Altemimi and N. Lakhssassi. 2019. A comprehensive review on medicinal plants as antimicrobial therapeutics: potential avenues of biocompatible drug discovery. Metabolites, 9: Article ID 258.

Aparna, V., D. Vijayan, P. Mandal and P. Karthe. 2012. Anti-inflammatory property of $n$-hexadecanoic acid: Structural evidence and kinetic assessment. Chem. Biol. Drug Des., 80: 434-439.

Balamurugan, R., V. Duraipandiyan and S. Ignacimuthu. 2011. Antidiabetic activity of $y$-sitosterol isolated from Lippia nodiflora L. in streptozotocin induced diabetic rats. Eur. J. Pharmacol., 667: 410-418.

Banaras, S., A. Javaid and I.H. Khan. 2021. Bioassays guided fractionation of Ageratum conyzoides extract for the identification of natural antifungal compounds against Macrophomina phaseolina. Int. J. Agric. Biol., 25(4): 761-767.
Bashir, A., K. Ibrar, B. Shumaila, S. Azam. 2012. Chemical composition and antifungal, phytotoxic, brine shrimp cytotoxicity, insecticidal, and antibacterial activities of the essential oils of Acacia modesta. J. Med. plants Res., 6: 4653-4659.

Boy, H.I.A., A.J.H. Rutilla, K.A. Santos, A.M.T. Ty, I.Y. Alicia, T. Mahboob and V. Nissapatorn. 2018. Recommended medicinal plants as source of natural products: a review. Dig. Chin. Med., 1: 131142.

Chandrasekaran, M., K. Kannathasan and V. Venkatesalu. 2008. Antimicrobial activity of fatty acid methyl esters of some members of Chenopodiaceae. Z. Naturforsch. C, 63: 331-336.

Chandrasekaran, M., A. Senthilkumar, V. Venkatesalu. 2011. Antibacterial and antifungal efficacy of fatty acid methyl esters from leaves of Sesuvium portulacastrum L. Eur. Rev. Med. Pharmcol. Sci., 15: 775780.

Duke, J.A. 1992. Handbook of phytochemical constituents of GRAS herbs and other economic plants. Boca Raton, FL. CRC Press.

Elleuch, L., M. Shaaban, S. Smaoui, L. Mellouli, I. Karray-Rebai, L.F.B. Fguira, K.A. Shaaban, H. Laatsch. 2010. Bioactive secondary metabolites from a new terrestrial Streptomyces sp. TN262. Appl. Biochem. Biotechnol., 162(2): 579593.

Ferdosi, M.F.H., I.H. Khan, A. Javaid, M. Nadeem and A. Munir. 2021. Biochemical profile of Calotropis procera flowers. Pak. J. Weed Sci. Res., 27(3): 341-349.

Ghisari, M. and E.C. Bonefeld-Jorgensen. 2009. Effects of plasticizers and their mixtures on estrogen receptor and thyroid hormone functions. Toxicol. Lett., 189: 67-77.

Godwin, A., B. A. Akinpelu, A. M. Makinde, M. A. Aderogba and O.O. Oyedapo. 2015. Identification of $n$ hexane fraction constituents of Archidium ohioense (Schimp. ex Mull) extract using GC-MS 
534 Malik F. H. Ferdosi, Iqra Haider Khan et al. GC-MS Analysis and Bioactive ....

technique. Brit. J. Pharmaceut. Res., 6: 366-375.

Hernández-Ceja, A., P.D. Loeza-Lara, F.J. Espinosa-García, Y.M. GarcíaRodríguez, J.R. Medina-Medrano, G.F. Gutiérrez-Hernández and L.F. Ceja-Torres. 2021. In vitro antifungal activity of plant extracts on pathogenic fungi of blueberry (Vaccinium sp.). Plants, 10: Article 852.

Hussain, A., M. Kanth, P.K. Mastva, M. Sharma, J. Tripath and M.A. Khan. 2019. Phytochemical analysis of the rhizomes of Bergenia ciliata (How) Sternb. J. Drug Deliv. Ther., 9: 412-416.

Javaid, A., U. Latif, N. Akhtar, D. Ahmed and S. Perveen. 2018. Molecular characterization of Fusarium moniliforme and its management by methanolic extract of Coronopus didymus. Pak. J. Bot., 50(5): 20692075.

Javaid, A., I.H. Khan and M.F.H. Ferdosi. 2021. Bioactive constituents of wild Cannabis sativa roots from Pakistan. Pak. J. Weed Sci. Res., 27(3): 359-368.

Javed, S., Z. Mahmood, K.M. Khan, S.D. Sarker, A. Javaid, I.H. Khan and A. Shoaib. 2021. Lupeol acetate as a potent antifungal compound against opportunistic human and phytopathogenic mold Macrophomina phaseolina. Sci. Rep., 11: 8417.

Khan, I.H. and A. Javaid. 2020a. Anticancer, antimicrobial and antioxidant compounds of quinoa inflorescence. Adv. Life Sci., 8(1): 68-72.

Khan, I.H. and A. Javaid. 2020b. Comparative antifungal potential of stem extracts of four quinoa varieties against Macrophomina phaseolina. Int. J. Agric. Biol., 24(3): 441-446.

Khan, I.H. and A. Javaid. 2020c. In vitro biocontrol potential of Trichoderma pseudokoningii against Macrophomina phaseolina. Int. J. Agric. Biol., 24(4): 730-736.

Khan, I.H., A. Javaid and D. Ahmed. 2021. Trichoderma viride controls Macrophomina phaseolina through its DNA disintegration and production of antifungal compounds. Int. J. Agric. Biol., 25(4): 888-894.

Kumar, P.P., S. Kumaravel and C. Lalitha. 2010. Screening of antioxidant activity, total phenolics and GC-MS study of Vitex negundo. Afr. J. Biochem. Res., 4: 191-195.

Kumar, P., K. Singh and S. Gairola. 2020. Botanical standardization of raw herbal drug Pashanabheda [Bergenia ciliata (Haw.) Sternb.] used in Indian systems of medicine. Plant Arch., 20: 864552.

Naqvi, S.F., I.H. Khan and A. Javaid. 2020. Hexane soluble bioactive components of Chenopodium murale stem. Pak. J. Weed Sci. Res., 26(4): 425-432.

Oladeji, O.S., F.E. Adelowo, D.T. Ayodele and K.A. Odelade. 2019. Phytochemistry and pharmacological activities of Cymbopogon citratus: A review. Sci. Afr., 6: e00137.

Oreopoulou, A., D. Tsimogiannis and V. Oreopoulou. 2019. Extraction of polyphenols from aromatic and medicinal plants: an overview of the methods and the effect of extraction parameters. In: Polyphenols in Plants, Isolation, Purification and Extract Preparation, Academic Press. pp. 243-259.

Peng, W., D. Li, M. Zhang, S. Ge, B. Mo, S. Li, M. Ohkoshi. 2017. Characteristics of antibacterial molecular activities in poplar wood extractives, Saudi J. Biol. Sci., 24: 399-404.

Rafiq, M., A. Javaid, A. Shoaib. 2021. Antifungal activity of methanolic leaf extract of Carthamus oxycantha against Rhizoctonia solani. Pak. J. Bot., 53(3): 11331139.

Rahuman, A.A., G. Gopalakrishnan, B.S. Ghouse, S. Arumugam and B. Himalayan. 2000. Effect of Feronia limonia on mosquito larvae. Fitoterapia, 71: 553-555.

Riaz, T., S.N. Khan and A. Javaid. 2008. Antifungal activity of plant extracts against Fusarium oxysporum - the 
cause of corm-rot disease of Gladiolus. Mycopath, 6: 13-15.

Salmerón-Manzano, E., J.A. GarridoCardenas and F. ManzanoAgugliaro. 2020. Worldwide research trends on medicinal plants. Int. J. Environ. Res. Public Health, 17: Article ID 3376.

Sermakkani, M. and V. Thangapandian. 2012. GC-MS analysis of Cassia italica leaf methanol extract. Asian J. Pharmaceut. Clin. Res., 2012;5(2):90-94.

Sirikhansaeng, P., T. Tanee, R. Sudmoon and A. Chaveerach. 2017. Major phytochemical as $y$-sitosterol disclosing and toxicity testing in Lagerstroemia species. Evid. Based Complement. Alternat. Med., 2017: Article 7209851.

Sundarraj, S., R. Thangam, V. Sreevani, K. Kaveri, P. Gunasekaran and S. Achiraman, S. Kannan. 2012. YSitosterol from Acacia nilotica L. induces G2/M cell cycle arrest and apoptosis through c-Myc suppression in MCF-7 and A549 cells. J. Ethnopharmacol., 141: 803-809.

Ugboko, H.U., O.C. Nwinyi, S.U. Oranusi, T.H. Fatoki and C.A. Omonhinmin. 2020. Antimicrobial importance of medicinal plants in Nigeria. Sci. World J., 2020: Article ID 7059323.

Vimalavady, A. and K. Kadavul. 2013. Phytocomponents identified on the various extracts of stem of Hugonia mystax L. (Linaceae). Pelagia Res. Libr. Eur. J. Exp. Biol., 3: 73-80.
Xue-Na, B., J. Cheng, W. Liang, M. LanQing, L. Yu-Bo, S. Guang-Lu and W. You-Nian. 2012. Antifungal activity of extracts by supercritical carbon dioxide extraction from roots of Stellera chamaejasme L. and analysis of their constituents using GC-MS. In Advances in Intelligent and Soft Computing; Zhu, E., Sambath, S., Eds.; Springer: Berlin/Heidelberg, Germany, Volume 134, pp. 653-662.

Yu, F.R., X.Z. Lian, H.Y. Guo, P.M. McGuire, R.D. Li, R. Wang, F.H. Yu. 2005. Isolation and characterrization of methyl esters and derivatives from Euphorbia kansui (Euphorbiaceae) and their inhibitory effects on the human SGC-7901 cells. J. Pharm. Pharm. Sci., 8: 528-535.

Zafar, R., H. Ullah, M. Zahoor and A. Sadiq. 2019. Isolation of bioactive compounds from Bergenia ciliata (haw.) Sternb rhizome and their antioxidant and anticholinesterase activities. BMC Complement. Altern. Med., 19: 1-13.

Zeidali, E., K.H. Mardani, Y. Alizadeh and F. Kamari. 2021. Ethnopharmacological survey of medicinal plants in semi-arid rangeland in western Iran. Central Asian J. Plant Sci. Innov., 1: 46-55. 